\title{
JEJAK WALI LIMBUNG DAN TRADISI JUM'AT PAHING DI KABUPATEN TEMANGGUNG JAWA TENGAH
}

\author{
THE FOOTSTEPS OF WALI LIMBUNG AND JUM'AT PAHING \\ TRADITION IN TEMANGGUNG REGENCY, CENTRAL JAVA
}

\author{
Syaifullah $^{1}$, Eqlima Dwiana Safitri ${ }^{2}$ \\ ${ }^{1}$ IAIN Surakarta, Jl. Pandawa, Dusun IV, Pucangan, Kec. Kartasura, \\ Kabupaten Sukoharjo, Jawa Tengah, 57168 Email: syaifullah366@ gmail.com \\ ${ }^{2}$ UIN Sunan Kalijaga Yogyakarta J1. Marsda Adisucipto Yogyakarta 55281 \\ e-mail: eqlima75@gmail.com
}

DOI: $10.36424 / j p s b . v 7 i 1.212$

Naskah Diterima: 31 Agustus 2020 Naskah Direvisi: 20 Mei 2021

Naskah Disetujui: 23 Mei 2021

\begin{abstract}
Abstrak
Wali limbung merupakan tokoh agama yang populer di Jawa Tengah, khususnya di daerah Temanggung. Meskipun beliau lahir beberapa abad yang silam, jejaknya masih terasa bahkan di era digital sekarang. Tulisan ini memaparkan historisitas jejak langkah wali limbung dan tradisi Jum'at pahing. Kajian ini menerapkan teori fungsionalisme Bronislow Malinowski. Teori ini menyatakan bahwa setiap unsur kebudayaan memiliki fungsi bagi masyarakat setempat. Data dikumpulkan melalui observasi, wawancara dan dokumentasi. Penelitian ini menggunakan metode kualitatif. Hasil penelitian ini berisi paparan tentang sejarah Wali Limbung, latar belakang dan tujuan tradisi Jum'at pahing. Latar belakang sejarahnya adalah peresmian penggunaan Masjid Jami' yang didirikan oleh Wali Limbung bertepatan dengan hari Jum'at pahing. Tujuan tradisi Jum'at pahing adalah memperoleh barokah dan keteguhan hidup.
\end{abstract}

Kata Kunci: Wali Limbung, Jum'at pahing, Bronislow Malinowski, Kebudayaan

\begin{abstract}
Wali Limbung is a popular religious figure in Central Java, especially in the Temanggung area. Even though he was born centuries ago, his traces are still felt even in today's digital era. This paper describes the historicity of the footsteps of wali limbung and the tradition of Friday pahing. This study applies Bronislow Malinowski's theory of functionalism. This theory states that every element of culture has a function for the local community. Data were collected through observation, interviews and documentation. This study uses a qualitative method. The results of this study contain descriptions of the history of Wali Limbung, the
\end{abstract}


background and objectives of the Jum'at pahing tradition. The historical background is the inauguration of the use of the Jami Mosque which was founded by Wali Limbung to coincide with Friday pahing. The goal of the Jum'at pahing tradition is to obtain blessings and life stability.

Keywords: Wali Limbung, pahing Friday, Bronislow Malinowski, Culture

\section{PENDAHULUAN}

Islam merupakan agama mayoritas di Nusantara yang memiliki ragam pemikiran dan ritual keagaaman. Masing-masing daerah memiliki perbedaan antara satu dengan daerah lainnya. Perbedaan ini tidak terlepas dari tokoh agama dan corak pemahaman bagaimana yang diyakini.

Pulau Jawa dikenal dengan Wali Songo yang memiliki peran peting dalam penyebaran agama Islam dan secara tidak langsung ikut mewarnai pemikiran dan ritual keagamaan. Keberadaan Wali di tanah Jawa berperan besar dalam penyebaran agama Islam (Maziyah, 2020: 235). Beberapa Wali sering memadukan unsur-unsur budaya dalam dakwahnya karena lebih mudah dipahami oleh masyarakat setempat dan juga budaya memiliki hubungan yang saling mempengaruhi dengan manusia. Hasil pemikiran, cipta, rasa dan karsa manusia merupakan kebudayaan yang berkembang pada masyarakat. Selain itu juga mencakup pikiran dan perbuatan dilakukan secara terus menerus. Kegiatan yang berlangsung secara terus menerus ini melahirkan tradisi, upacara-upacara tertentu hingga sistem kepercayaan masyarakat (Koentjaraningrat, 1984: 322).

Suatu kebudayaan yang melahirkan tradisi upacara yang mengandung unsur religi dalam masyarakat Jawa sulit untuk berubah karena berkaitan erat dengan kepercayaan yang diyakini oleh masyarakat Jawa (Purwadi, 2007: 93). Tradisi ritual keagamaan yang lahir dari kebudayaan masyarakat senantiasa berkembang dalam masyarakat dan dijalankan dari generasi ke generasi tanpa atau dengan perubahan yang mendasar.

Literatur klasik banyak menyatakan bahwa ulama Timur Tengah dan ulama Nusantara telah melakukan konsolidasi demi menyebarkan agama Islam hingga ke seluruh pelosok Nusantara (Syawal, 2019: 190). Salah satu ulama yang kemudian dikenal dengan nama Wali Limbung adalah satu dari sekian banyak 
ulama yang dimaksud. Wali Limbung memiliki jejak dan warisan berupa tradisi keagamaan yang hingga saat ini masih lestari. Adapun tradisi yang dimaksud adalah tradisi Jum'at pahing untuk menunaikan nazar ${ }^{1}$. Tradisi keagaaman tersebut memiliki nilai-nilai dan kearifan lokal (Buhori, 2017: 233).

Menurut masyarakat yang masih melestarikan tradisi hari istimewa itu adalah hari Jum'at pahing. Hari yang tepat untuk memanjatkan permohonan kepada Allah dan membayar nazar di makam Wali Limbung. Tradisi Jum'at pahing bisa dilakukan secara perorangan maupun kelompok oleh jama'ah setempat. Selain itu, ritual malam Jum'at pahing yang mencakup pembacaan yasin, tahlilan dan wirid juga dilakukan di makam Wali Limbung.

Setiap komunitas memiliki kearifan dan pengetahuan lokal yang merupakan hasil komunikasi dan interaksi antar manusia dengan alam untuk bertahan hidup (Amady, 2020: 148). Hal ini juga dapat diamati pada tradisi Jum'at pahing dan ziarah di makam Wali Limbung.

Tradisi Jum'at pahing ini muncul setelah wafatnya seorang Wali yang dikenal dengan nama Wali Limbung. Beliau berdakwah menyebarkan ajaran Islam di pulau Jawa, khususnya di daerah Klimbungan, Ngadirejo, Temanggung. Pemilihan hari Jum'at sebagai waktu berlangsungnya ritual tidak terlepas dari peresmian Masjid Jami' yang didirikan oleh Wali Limbung pada hari Jum'at pahing.

Tradisi Jum'at pahing sangat menarik untuk diteliti karena masih lestari sampai sekarang. Memiliki nilai dan fungsi bagi masyarakat lokal. Berangkat dari paparan di atas tulisan ini bermaksud memaparkan jejak Wali Limbung, bagaimana tujuan dan manfaat tradisi Jum'at pahing.

\section{METODE PENELITIAN}

Penelitian ini berlokasi di makam Wali Limbung tepatnya di dusun Kawangan, Ngadirejo, Temanggung, Jawa Tengah. Penelitian ini menggunakan pendekatan kualitatif dengan objek materilnya adalah sejarah Wali Limbung dan

\footnotetext{
${ }^{1}$ Nazar secara bahasa adalah janji, dan secara istilah adalah janji pada diri sendiri hendak melakukan sesuatu jika maksutnya atau cita-citanya tercapai.
} 
tradisi Jum'at pahing. Pendekatan kualitatif digunakan untuk meneliti objek kajian yang bersifat alamiah yang berlawanan dengan eksperimen yang mana peneliti merupakan instrumen kunci. Jika ditinjau dari pemerolehan data maka penelitian ini bisa dikategorikan ke dalam penelitian lapangan (Saleh, 2019: 261).

Pendekatan kualitatif diawali dengan mendeskripsikan ucapan, tulisan dan perilaku yang diamati baik dari perilaku penziarah maupun warga setempat (Maryaeni, 2005: 25). Pada tahap berikutnya setelah data dideskripsikan, lalu dikumpulkan dan dikelompokkan data yang relevan untuk dianalisis dengan menggunakan teori fungsionalisme.

Teori fungsionalisme menjelaskan bahwa aktivitas kebudayaan diharapkan mampu memberikan manfaat pada semua aktivitas dan kebutuhan naluriyah manusia (Gazalba, 1968: 118). Kebudayaan semestinya dapat memenuhi kebutuhan biologis, psikologis dan tidak terkecuali dalam lingkup sosial budaya. Karena setiap aktivitas yang menjadi kebiasaan, kepercayaan dan sikap yang merupakan bagian dari kebudayaan itu sendiri pada dasarnya dapat memenuhi beberapa fungsi primer dalam kehidupan masyarakat. Penelitian ini diharapkan dapat mengungkapkan fungsi dari tradisi Jum'at pahing yang mana sampai saat ini masih lestari.

\section{PEMBAHASAN}

\section{Jejak Wali Limbung}

Wali Limbung merupakan pendakwah $\left(d a^{\prime} i\right)$ di kabupaten Temanggung yang mana kepopulerannya masih dapat dirasakan hingga saat ini. Wali Limbung meninggalkan sebuah Masjid yang sampai saat ini masih dijadikan sebagai sebuah struktur agamawi untuk melaksanakan ritual keagamaan seperti salat lima waktu, salat Jum'at dan ibadah-ibadah lainnya. Masjid peninggalan dari Wali ini telah mengalami renovasi dan dijadikan sebagai wisata religi. Letak Masjid ini berada di sebelah barat laut makamnya yaitu di Dusun Kawangan, Kecamatan Ngadirejo, Kabupaten Temanggung. Masjid ini dinamai dengan Masjid Jami’ Wali Limbung.

Wali Limbung lahir pada zaman penjajahan Belanda yaitu ketika terjadi konflik antara Mataram dengan VOC di Batavia dengan nama asli Klana Jiwa 
(Jiwa yang berkelana). Menurut warga setempat (wawancara dengan Ruswandi tanggal 7 Oktober, 2016), Wali Limbung adalah keturunan Jawa yang merupakan putra dari Sultan Agung penguasa Mataram Islam. Pada saat terjadi perseteruan antara Mataram Islam dengan VOC, Sultan Agung membawa salah satu selirnya yang mana dalam keadaan hamil. Dalam perjalanan itu, Sultan Agung memberi perintah kepada Patihnya agar membawa pulang selirnya melewati jalur Utara.

Adapun jalur Utara melewati rute Temanggung untuk sampai ke Ibukota Mataram. Dalam perjalanan inilah selirnya merasa akan melahirkan dan perutnya semakin membesar hingga berakibat jalannya tidak lancar atau tegak. Kondisi yang demikian dalam tuturan masyarakat Jawa disebut limbung yaitu suatu kondisi berjalan limbung/sempoyongan. Dalam waktu yang begitu singkat, selir Sultan Agung pun melahirkan di tempat tersebut yang sampai saat ini daerah tersebut populer dengan sebutan dusun Klimbungan.

Setelah lahir di daerah tersebut, Wali Limbung menetap dengan ibu dan ayah angkatnya, yang bernama Patih Mataram. Di daerah tempat lahirnya Wali Limbung didirikan sebuah padepokan yang ramai dikunjungi oleh banyak penduduk pribumi untuk meminta petunjuk, berdiskusi, berkonsultasi bahkan menuntut ilmu. Keadaan mengunjungi Padepokan ini oleh masyarakat lokal disebut marak disebabkan maraknya pengunjung padepokan tersebut. Melihat keadaan yang demikian didirikanlah pondok pesantren Kyai Parak yang terdapat di jalan Parakan-Kedu Temanggung. Setelah Wali Limbung beranjak dewasa dan memiliki kedalaman pengetahuan Agama sehingga menjadi seorang tokoh Islam didirikan pula Pondok Kyai Parak Tsani yang berlokasi di Parakan.

Sejarah Wali Limbung juga memiliki versi lain dalam kemunculannya di Dusun Klimbungan. Versi ini mengemukakan bahwa Wali Limbung merupakan rombongan Syekh Maulana Malik Ibrahim yang datang ke tanah Jawa dengan misi menyebarkan Islam. Menurut sumber ini Wali Limbung merupakan gelar dari nama asli Sayyid Abdullah Qudsi. Wali Limbung tiba di Gresik tahun 1379 M yang mana ini mengindikasikan bahwa ia hidup pada zaman Wali Sanga atau satu periode waktu dengan Syekh Maulana Malik Ibrahim (Affandi, 1978: 6). 
Jejak Wali Limbung yang masih dapat disaksikan adalah bedug, mimbar untuk Khotbah, tongkat, bandosa/ keranda pengusung jenazah dan makam yang terletak di Dusun Kawangan. Makam Wali Limbung dipercaya oleh sebagian penduduk sebagai salah satu makam keramat. Dalam artian lain memiliki keajaiban tersendiri bagi pengunjung makam tersebut.

\section{Latar Belakang Munculnya Tradisi Jum'at Pahing}

Salah satu ritual dari Wali Limbung adalah ahli riyadhah. Adapun bekas ia biasa beriyadhah ${ }^{2}$ dikenal dengan istilah panepen yang berarti tempat nyepi (mengasingkan diri dalam kesunyian). Di lokasi panepen ini ada sumber/mata air untuk bersuci yang mana menurut warga setempat cukup untuk keperluan Masjid.

Sebagai sarana untuk bertabligh dan tempat beribadah bagi umat Islam, maka pada awal abad XVI, Wali Limbung mendirikan masjid yang terletak \pm 200 Meter dari Panepen. Adapun peresmian penggunaan masjid tersebut pada suatu hari Jum'at pahing. Keyakinan hari Jum'at pahing sebagai hari jadi Masjid Jami' Wali Limbung ini secara turun temurun telah membudaya bagi masyarakat setempat untuk memperingati hari Jum'at pahing sebagai hari jadi masjid Wali Limbung. Masyarakat Klimbungan dan sekitarnya yang hendak berziarah, beriyadhah maupun bernazar, dilakukan pada hari Jum'at pahing. Hal ini berlangsung sejak zaman dahulu kala dan turun temurun.

Setelah Wali Limbung wafat/meninggal dunia, ia dimakamkan di Dusun Kawangan tepatnya $\pm 2 \mathrm{Km}$ sebelah barat laut Dusun Klimbungan. Konon pada waktu mengusung jenazahnya, rute perjalanannya melewati Desa Banjarsari. Sesampai di Desa Banjarsari, mereka berhenti sampai waktu yang lama. Tempat mereka berhenti diberi nama janggleng, menurut istilah setempat berhenti menunggu sampai waktu lama. Sampai sekarang di janggleng pada tiap hari Jum'at pahing ada pasar kecil tempat midag (menunaikan nazar). Bagi peziarah makam Wali Limbung seyogyanya melewati Banjarsari, melewati rute perjalanan jenazah Wali Limbung.

\footnotetext{
${ }^{2}$ Suatu cara untuk melatih jiwa dan nafsu agar dapat melawan kecenderungan-kecenderungan yang buruk
} 
Tradisi ziarah ke makam Wali Limbung oleh sebagian pengunjung sudah dianggap sebagai rutinitas dalam kehidupan spiritual mereka. Hal ini diyakini dengan adanya keterangan bahwa kedatangan mereka ke makam Wali Limbung tidak hanya sekali atau dua kali saja, tetapi ada yang lebih dari tiga kali, bahkan sering datang. Rutinitas ziarah ini sudah berlangsung bertahun-tahun. Keyakinan ziarah ke makam pada dasarnya sudah ada sejak Islam belum masuk ke Indonesia. Ketika Islam datang dengan membawa konsep ziarah, dengan cepat diterima oleh masyarakat sekitar. Menurut Islam sendiri konsep ziarah berasal dari hadist Rasulullah yang artinya:

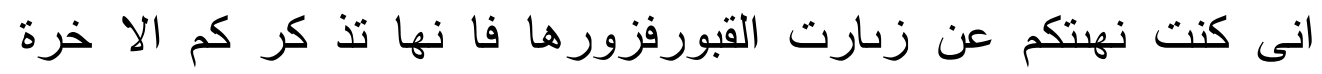

"Dulu aku telah melarang kamu menziarahi kubur, sekarang ziarahilah ia, karena ziarah kubur mengingatkan kamu akan akhirat". (HR. Muslim)

Dengan adanya anjuran tersebut, oleh sebagian umat Islam dijadikan sarana untuk mendekatkan diri kepada Allah SWT. Begitu juga dengan pengunjung makam Wali Limbung, mereka datang dengan keyakinan bahwa makam para leluhur memiliki nilai-nilai khusus bagi yang bersangkutan. Mereka yakin bahwa leluhurnya dapat dimintai barokah atau pertolongan. Akan halnya fenomena yang terjadi di makam Wali Limbung, sehingga ada pernyataan yang cukup relevan dengan adanya asumsi bahwa: sesungguhnya pencari barokah pada orang yang shaleh, pada sisa-sisa peninggalannya, pada waktu dan tempat-tempat tertentu yang ada kaitannya dengan mereka, merupakan masalah penting yang menyangkut aqidah (wawancara dengan Suryo, 24 Januari 2016). Pengunjung makam Wali Limbung meyakini di samping untuk mendekatkan diri kepada Allah, juga dapat meminta barokah dari Wali Limbung supaya urusannya dimudahkan oleh Allah dan cita-citanya dapat tercapai (wawancara dengan Abdul Rahman, 29 Januari 2016).

Banyak sekali kita jumpai orang yang mendatangi tempat-tempat yang dianggap keramat untuk berziarah dan melakukan ritual di sana. Mereka datang dari berbagai daerah supaya keinginannya dikabulkan oleh Allah SWT, setelah mereka melakukan ritual di tempat atau makam yang dianggap keramat tersebut. 
Dalam hal ini makam Wali Limbung sebagai sentral berziarah, karena dianggap tempat yang keramat, dimana seorang Waliyullah di makamkan.

Waktu yang dianggap paling representatif ketika berziarah di makam Wali Limbung adalah hari Jum'at pahing sehingga pada hari tersebut banyak peziarah yang melakukan ritual di makam tersebut. Sebagian besar peziarah yang mendatangi makam Wali Limbung bertujuan untuk meminta barokah. Mereka datang dari berbagai daerah, ada yang dari daerah setempat ada pula yang dari luar daerah, misalkan Jawa Timur, Jawa Barat, Sumatera, Kalimantan, dan lain sebagainya.

Banyak peziarah dari luar daerah yang datang ke makam Wali Limbung, misalkan Ustadz Ahmad dari Jawa Timur. Beliau mengetahui makam Wali Limbung dari gurunya KH. Fathu Amin, yang bertempat tinggal di daerah Ampel, Surabaya. Beliau adalah keturunan dari Sunan Ampel yang sekarang memimpin Pondok Pesantren di Ampel. KH. Abdul Haq dari Magelang, ia sering memimpin jama'ahnya yang berjumlah kurang lebih 1500 orang untuk melakukan ritual di makam Wali Limbung (wawancara dengan Suryo, 24 Januari 2016). Kemudian, masih banyak lagi peziarah dari daerah lain yang datang ke makam Wali Limbung.

Sebagian besar peziarah memiliki tujuan yang sama, yaitu meminta barokah. Peziarah yang sudah berkunjung ke makam Wali Limbung, mereka merasakan kedamaian ketika berada di makam dan setelah pulang dari makam. Setelah melakukan ritual di makam, disamping mendapatkan ketenangan juga akan merasa mendapatkan barokah dari Wali Limbung sehingga keinginannya dikabulkan oleh Allah SWT.

\section{Prosesi Pelaksanaan Tradisi Jum'at Pahing}

Sebuah tradisi unik sejak dahulu berada di makam Wali Limbung yang terletak di Dusun Kawangan dan di Pasar Janggleng yang terletak di Desa Banjarsari ini adalah tradisi yang dapat dijadikan sebagai wisata religi, yaitu pada hari Jum'at pahing. Pada pagi hari banyak masyarakat sekitar dan luar daerah berkunjung ke Pasar Janggleng lalu ke makam Wali Limbung. Berdasarkan 
wawancara dengan juru kunci Pasar Janggleng, juru kunci makam, masyarakat setempat, serta pengunjung yang datang ke pasar maupun ke makam, mereka mengatakan bahwa pengunjung tidak hanya dari daerah lokal, namun dari luar kota seperti Jawa Timur, Jawa Barat, Yogyakarta, Pekalongan, Wonosobo, Kalimantan, Sumatera, dan masih banyak daerah yang lain.

\section{Prosesi pelaksanaan ritual di makam Wali Limbung}

Sebenarnya yang terjadi di makam Wali Limbung tidak jauh berbeda dengan ritual-ritual di makam lain. Ritual yang dilakukan di makam Wali Limbung sangat heterogen, ada yang membaca tahlil, membaca al-Qur'an, membaca Asma Allah dan ada juga yang mengawali ritualnya dengan membakar kemenyan dan dupa sebelum melakukan ritual. Rata-rata peziarah melakukan ritual dengan membaca tahlil. Meskipun ritual yang mereka lakukan berbeda namun pada dasarnya mereka mempunyai tujuan yang sama, yaitu meminta barokah supaya keinginannya dapat dikabulkan oleh Allah SWT.

Dalam hal ini, makam Wali Limbung sebagai sentral ziarah, yang diyakini dapat memberikan barokah. Ritual di makam Wali Limbung dilakukan secara kelompok, namun ada juga yang perorangan seperti yang dilakukan oleh Bapak Sutrisno dari Sukorejo yang datang untuk berziarah dan meminta barokah. Bapak Sutrisno mengatakan, "kalau besok saya atau anak saya sembuh dari sakit, atau besok kalau usaha saya berhasil, maka saya akan Jum'at pahingan di Pasar Janggleng dan rasulan di makam Mbah Wali”. Memang yang namanya nazar kalau sudah diikrarkan, apalagi ikrar di hadapan Allah maka hukumnya wajib dilaksanakan. Itulah sebabnya mereka rela datang jauh-jauh karena berniat untuk melaksanakan nazar.

\section{Ritual ziarah makam Wali Limbung}

Bagi masyarakat Jawa, makam merupakan tempat yang dianggap suci dan pantas dihormati. Makam sebagai tempat peristirahatan bagi arwah nenek moyang dan keluarga yang telah meninggal. Keberadaan makam dari tokoh tertentu menimbulkan daya tarik bagi masyarakat untuk melakukan aktifitas ziarah dengan berbagai motivasi. Makam, terutama makam tokoh sejarah, tokoh 
mitos atau tokoh agama juga merupakan tujuan wisata rohani yang banyak dikunjungi wisatawan baik dalam negeri maupun luar negeri.

Secara umum tujuan ziarah selain sebagai ungkapan do'a dan pengenalan akan sejarah nenek moyang, masih ada motivasi ziarah yang berkembang dalam masyarakat, seperti di makam Wali Limbung. Di makam tersebut pada hari-hari tertentu ramai dikunjungi peziarah yaitu hari Jum'at pahing. Para peziarah datang dengan berbagai motivasi dan tujuan, yaitu untuk memperoleh barokah dan keteguhan hidup (ngalap barokah), untuk memperoleh kekuatan, popularitas, mencari ketenangan batin, mencari kekayaan dunia maupun jabatan duniawi atau mencari rezeki, upaya mencari kebahagiaan anak cucu supaya selamat atau untuk mencari keselamatan, untuk meminta kesembuhan dan lain sebagainya.

Makam Wali Limbung selalu ramai dikunjungi oleh para peziarah yang akan melaksanakan ritual di makam. Bagi peziarah yang akan melaksanakan ziarah kubur dapat melaksanakannya sewaktu-waktu. Akan tetapi, makam Wali Limbung akan mencapai puncak keramaian pada hari Jum'at pahing.

Ritual yang dilaksanakan di makam Wali Limbung tidak jauh berbeda dengan ritual di makam-makam lain. Namun tidak semua makam akan dikunjungi oleh banyak peziarah kecuali makam tersebut termasuk makam nenek moyang, keramat, waliyullah, dan lain sebagainya.

Peziarah yang akan melaksanakan ritual dianjurkan untuk bersuci terlebih dahulu. Setelah bersuci, diperkenankan masuk ke area makam dan melaksanakan ritual. Ritual tersebut dilakukan oleh perseorangan maupun kelompok, ada yang membaca tahlil, yasin, Al-Qur'an, Asmaul Husna, dan lain sebagainya. Adapun bagi mereka yang ingin bernazar dapat menambahkan do'a secara khusus. Tidak sedikit dari mereka yang mengawali ritual tersebut dengan membakar kemenyan terlebih dahulu. Dalam melaksanakan ritual ziarah makam, hendaknya dilakukan dengan penuh rasa hormat dan khidmat serta khusyu, supaya do'anya terkabul, sehingga yang menjadi keinginan dapat terwujud (wawancara dengan Tamiyis, 7 Februari 2016). Adapun rangkaian dan urutan bacaan tahlil yang pada umumnya dilaksanakan dan berlaku di masyarakat adalah sebagai berikut: 
Pertama, Tawasul. Tawasul secara tematik artinya mengambil perantara (Fattah, 2016: 316) atau sesuatu yang dijadikan untuk mendekatkan diri (Tawajjuh) kepada Allah Swt. Guna mencapai sesuatu yang diharapkan dari-Nya. Bacaan tawassul bisa bermacam-macam, akan tetapi intinya adalah mengalamatkan pahala bacaan tahlil kepada arwah yang hendak dihadiahi, mulai dari Nabi Muhammad SAW, Syaikh Abdul Qadir al-Jaelani, para alim ulama, arwah keluarga, dan yang terahir untuk kaum muslim secara umum.

Kedua, pembacaan surat al-Ikhlas, surat al-Falaq, surat an-Nas, dan alFatihah masing-masing 3x. Ketiga, Permulaan Surat al-Baqarah. Keempat, Ayat Kursi. Kelima, Istigfar dibaca 3x.

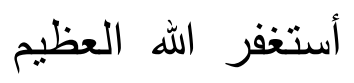

Artinya: "Saya mohon ampun kepada Allah Yang Maha Agung."

Keenam, Dzikir dibaca 21x, adapun dzikir yang sering dibaca adalah:

لا لا اله الا الله

Artinya: "Tiada Tuhan selain Allah."

Ketujuh, Shalawat.

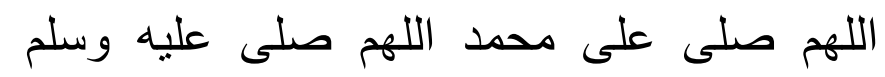

Artinya: "Ya Allah, tabahkanlah kesejahteraan kepada Muhamma. Ya Allah tambahkanlah kesejahteraan dan keselamatan kepadanya."

Kedelapan, tasbih dibaca 33x.

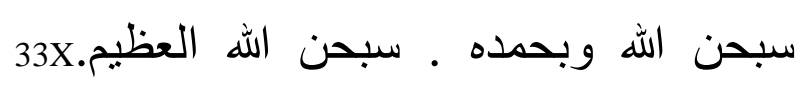

Artinya: "Maha Suci Allah dan dengan memuji-Nya 33x. Maha suci Allah Yang Maha Agung."

Kesembilan, al-Fatihah.

Terakhir, do'a penutup. 
Do'a dalam Islam adalah memohon kepada Allah supaya diberikan keselamatan dan kesejahteraan. Dengan demikian, do'a berarti manusia itu harus selalu ingat kepada Allah dan manusia selalu tergantung kepadanya (sari pati penghambaan diri kepada Allah) (H.M Machan Anies, 2009: 19). Berdo'a dalam ziarah makam dibaca paling akhir. Do'a tahlil ini dibaca sekali dalam melaksanakan ziarah makam, untuk yang berkelompok dipimpin oleh orang yang dipercaya dan fasih dalam berdo'a. Secara bahasa, tahlil berarti mengucapkan kalimat lailahaillallah (tiada Tuhan selain Allah).

Masyarakat yang melaksanakan ziarah ke makam Wali Limbung memiliki tujuan masing-masing. Menurut Bapak Rohadi dari Parakan, ia berziarah dengan tujuan memohon ampun kepada Allah, mendo'akan Wali Limbung, rizki murah barokah, dan semoga Allah meridhoi atas segala usahanya. Menurut Ibu Marfu'ah, ia berziarah ke makam Wali Limbung dengan maksud meminta barokah supaya Wali Limbung dapat mendo'akan Ibu Mar'fuah sekeluarga, supaya Allah menyembuhkan anaknya yang sedang sakit tifus. Menurut mas Rohman dari Pringapus, ia berziarah ke makam Wali Limbung dengan tujuan untuk mendapat ketenangan batin dan mendapatkan barokah supaya ia segera dipertemukan dengan jodohnya. Menurut bapak Rohimin dari Ngadirejo, ia berziarah dengan tujuan mendo'akan leluhur dan mendapatkan barokahnya supaya Allah mengabulkan hajatnya.

Peziarah lokal biasanya akan mencapai puncaknya apabila mendekati musim tembakau yang dimulai dari musim tanam sampai musim panen yaitu bulan Maret sampai September. Biasanya di bulan ini ramai sekali peziarah lokal yang berdatangan. Kedatangan mereka tidak lain adalah untuk bertabarruk atau mencari barokah supaya dalam musim tembakau mereka dapat sukses dan mendapatkan hasil dan untung yang besar. Hal ini dilakukan oleh penduduk setempat dan penduduk di sekitar makam yang berprofesi sebagai petani tembakau. Tidak berhenti sampai disini saja, setelah keinginan mereka terkabul, maka setelah musim panen selesai mereka mengadakan ritual Rasulan dengan tujuan bersyukur dan berterima kasih kepada Allah, karena mereka dapat sukses setelah mereka berziarah di makam Wali Limbung. 
Dari sekian banyak peziarah yang datang ke makam Wali Limbung, dengan maksud mendo'akan arwah leluhur dalam hal ini, Wali Limbung. Hal tersebut bertujuan supaya Wali Limbung juga mendo'akannya dan memberikan barokah kepadanya (wawancara dengan Peno, 7 Februari 2016).

\section{Ritual Menunaikan Nazar di Makam Wali Limbung}

Prosesi ritual menunaikan nazar di makam Wali Limbung diawali dengan bersih makam yang dimulai dari pukul 05.30-07.30 WIB. Masyarakat Dusun Kawangan khususnya pemuda dan bapak-bapak berbondong-bondong pergi ke makam untuk membersihkan makam. Pembersihan makam dibagi beberapa kelompok yaitu membersihkan jalan menuju makam, membersihkan makam, membersihkan mushola dan kamar mandi.

Setelah selesai melakukan pembersihan makam, ritual menunaikan nazar dimulai dengan dipimpin oleh juru kunci makam Wali Limbung yaitu Bapak Abdul Rahman. Setelah pemuda dan bapak-bapak duduk bersama dan bersila, kemudian juru Kunci membuka acara, isinya bermaksud untuk mengucapkan rasa syukur dan berterima kasih kepada masyarakat yang sudah bersedia melaksanakan rutinitas bersih makam dan mengikuti acara Rosulan ini. Selain itu juru kunci juga memimpin do'a yang isinya mengucapkan rasa syukur karena keinginan dari penazar telah dikabulkan, memohon maaf dan ampunan dosa para leluhur atau pribadi mereka kepada Tuhan yang Maha Esa.

Acara tersebut tidak hanya dihadiri oleh pemuda dan bapak-bapak saja, namun terkadang ibu-ibu dan anak-anak juga datang dalam acara tersebut. Selesai berdo'a, penazar memberikan apa yang telah dinazarkan tersebut kepada juru kunci. Hal ini mereka lakukan supaya afdhol dan sah. Untuk melengkapi nazarnya, mereka biasanya membawa kembang boreh yang dibeli dari Pasar Janggleng, yang nantinya kembang boreh tersebut diletakkan di atas makam Wali Limbung atau makam Kyai Kawang.

Setelah juru kunci menerima, maka yang berupa makanan diletakkan di tampah dan yang berupa uang dimasukkan ke kotak amal. Biasanya, sebelum makanan dihidangkan, juru kunci terlebih dahulu mengambil jatah untuk dibawa 
pulang dan memberikannya sedikit kepada penazar untuk dibawa pulang kembali. Hal ini mereka lakukan karena makanan tersebut mengandung barokah dari Wali Limbung. Acara menunaikan nazar tidak pasti setelah bersih makam, tetapi ada juga yang dilakukan pada siang, sore, dan malam hari yang tepatnya di hari Jum'at pahing.

Menurut Mas Amin, ia datang ke makam Wali Limbung dengan tujuan untuk Jum'at pahingan di makam Wali Limbung karena dahulu pernah bernazar kalau ia mendapatkan pekerjaan maka ia akan Jum'at pahingan di makam Wali Limbung. Setelah keinginan Mas Amin terkabul, ia melaksanakan ritual menunaikan nazar di makam Wali Limbung.

Ritual menunaikan nazar ini diadakan di makam Wali Limbung, tepatnya di hari Jum'at pahing. Sebab hari Jum'at pahing merupakan hari yang representatif untuk menunaikan nazar, karena hari Jum'at pahing merupakan hari jadi Masjid Jami' Wali Limbung yang berada di Dusun Klimbungan, Desa Medari, Kecamatan Ngadirejo, Kabupaten Temanggung. Bancakan ${ }^{3}$ nazar dilakukan secara insidentil, dilakukan oleh para peziarah yang do'anya terkabul ketika dipanjatkan di makam Wali Limbung. Tidak ada aturan resmi tentang hidangan yang harus disajikan pada bancakan nazar ini. Biasanya mereka membawa sego rosulan lengkap dengan ingkungnya. Adapun hidangan itu biasanya dibagikan kepada peziarah lain ataupun dibawa pulang oleh penduduk di sekitar makam.

\section{Prosesi pelaksanaan tradisi di Pasar Janggleng}

Pasar Janggleng terletak di Balai Desa Banjarsari yang letaknya tidak jauh dari makam Wali Limbung. Jarak antara makam Wali Limbung dan pasar \pm 1 KM. Pasar Janggleng dahulu termasuk petilasan dari Wali Limbung. Mbah Wali dulu pernah bersabda, "sesok ning kene iki bakalan dadi pasar rame sak rejehe zaman“ (besok di tempat ini akan menjadi pasar yang rame seperti ramainya zaman), yaitu pasar Janggleng (wawancara dengan Bolot, 7 Februari 2016). Di Balai Desa terdapat mushola yang dibangun oleh masyarakat setempat. Mushola

\footnotetext{
${ }^{3}$ Arti kata bancakan adalah selamatan atau hidangan yang disediakan di selamatan.
} 
ini ada yang menunggui yaitu Kyai Janggleng. Kyai Janggleng adalah salah satu murid dari Wali Limbung.

Pasar ini diadakan hanya pada hari Jum'at pahing pagi. Dimulai dari pukul 04.30-08.00 WIB. Pukul 04.30 Wib, para pedagang menyiapkan dagangannya. Para penjual di Pasar Janggleng adalah turun temurun. Dagangan yang dijual di pasar tersebut yaitu kembang boreh, jajanan pasar, lauk-pauk, mainan anak-anak, dan lain sebagainya. Yang menjadi daya tarik tersendiri bagi para pengunjung yaitu adanya kembang boreh yang konon kembang boreh ini sebagai penolak balak.

Pukul 04.45 Pasar Janggleng sudah ramai pengunjung. Pengunjung yang datang ke pasar ini tidak hanya masyarakat Banjarsari, namun dari masyarakat luar pun ikut berdesak-desakkan di pasar tersebut. Kedatangan para pengunjung ke pasar ini dengan tujuan untuk menunaikan nazar, ada yang sudah sembuh dari sakit, ada yang datang supaya sembuh dari sakit, supaya segera mendapatkan momongan, dan lain sebagainya. Seperti yang diungkapkan oleh Ibu Romiyah dari Desa Katekan, ia datang ke Pasar Janggleng tujuannya untuk menunaikan nazar, karena anaknya telah sembuh dari sakit. Lain halnya dengan Mbak Siti dari Pringsewu, ia datang ke Pasar Janggleng bersama suaminya karena ia sudah lama menikah tetapi belum dikaruniai anak, sehingga mereka datang supaya segera dikaruniai anak.

Para pengunjung yang datang ke Pasar Janggleng pertama menuju ke penjual kembang boreh, untuk membeli kembang boreh dan untuk mendapatkan olesan enjet (batu kapur atau gamping). Kembang boreh ini berisikan bunga mawar yang dicampur dengan irisan daun pandan dan enjet. Kembang boreh dijual dengan harga yang tidak ditentukan, sehingga para pengunjung membelinya dengan memberikan uang seikhlasnya pada si penjual. Setelah mendapatkan kembang boreh, maka kembang boreh tersebut diisi dengan uang receh, dalam istilah masyarakat setempat sebagai emas kawin. Kembang boreh yang sudah diisi uang receh, selanjutnya dibuang di jalan keluar dari lokasi pasar atau diperempatan jalan, hal ini mereka lakukan supaya dapat menolak balak. 
Bagi para pengunjung yang sakit, mereka membeli kembang boreh dan tidak lupa meminta si penjual untuk mengoleskan enjetnya ke bagian yang sakit. Hal ini mereka lakukan, karena mereka percaya bahwa hal tersebut dapat menyembuhkan penyakit. Tidak hanya manusia yang datang ke Pasar Janggleng, namun hewan pun turut serta meramaikan pasar tersebut. Para pemilik hewan ternak membawa ternaknya ke pasar tersebut untuk diborehi supaya bisa beranak banyak atau banyak bertelur. Sehingga para peternak bisa mendapatkan keuntungan dari peternakan tersebut.

Setelah melaksanakan ritual tersebut maka para pengunjung membeli oleholeh untuk dibawa pulang. Mereka tidak melewatkan untuk membeli juadah pasar di Pasar Janggleng. Juadah pasar yang dijual di Pasar Janggleng 98\% akan habis dalam waktu singkat karena apapun yang dijual di Pasar Janggleng adalah mengandung barokah (wawancara dengan Bolot, 7 Februari 2016).

Di Balai Desa Banjarsari juga terdapat sebuah air yang Mbah Bolot (juru kunci Pasar Janggleng) katakan bahwa air tersebut adalah air karomah. Masyarakat setempat mengatakan air tersebut adalah air seribu jalan yang artinya air yang mengandung seribu manfaat.

Asal air karomahpun tidak terdapat sejarah yang jelas, tetapi konon tempat pengambilan air tersebut dulu dibangun oleh masyarakat setempat dan airnya dari Kali Sengon. Tempat pengambilan air karomah tersebut hanya dapat diambil ketika hari Jum'at pahing saja. Disekitar tempat pengambilan air tersebut terdapat dupa, kemenyan, dan kembang boreh.

Masyarakat sekitar mempercayai bahwa air tersebut merupakan karamah dari Waliyullah dan memiliki khasiat sesuai dengan kebutuhan badan. Beberapa yang peneliti wawancarai, rasa dari air karamahpun bermacam-macam, ada yang terasa asin dan terasa biasa saja seperti air mineral pada umumnya. Bahkan ada yang mengatakan bahwa air karamah tersebut terasa seperti air zam-zam.

Terhadap air karamah yang terdapat di Petilasan seorang Wali, dimanfaatkan dengan cara yang berbeda-beda. Ada yang meminum langsung di tempat, ada yang minum dan membawa pulang serta dimasukkan ke dalam plastik yang sudah tersedia di tempat atau botol yang dibawa dari rumah. 


\section{Tujuan Tradisi Jum'at Pahing}

Ziarah merupakan ritual keagamaan yang diyakini dan ditunaikan oleh sebagian besar masyarakat muslim (Najitama, 2018: 19). Tentu tidak semua kaum muslimin melakukan ziarah ke makam Wali atau orang saleh. Namun, dibalik semua itu ritual ziarah ke makam memiliki tujuan dan misi tertentu tidak terkecuali pada tradisi Jum'at pahing.

Suatu ucapan, pernyataan maupun tindakan dalam memahaminya diperlukan adanya makna dan tujuan dibaliknya (Syahdan, 2017: 96). Dalam tradisi Jum'at pahing tentu tidak terlepas dari tujuan yang menyertai. Setidaknya ada beberapa tujuan diadakannya tradisi Jum'at pahing:

Pertama, Silaturahim. Berdasarkan pengamatan yang telah dilakukan di lapangan terlihat adanya saling mengunjungi dan hadirnya perasaan senasib. Selain itu, dalam tradisi Jum'at pahing juga terdapat rasa kebersamaan yang kuat antara penziarah dengan penziarah lainnya dan juga warga setempat.

Kedua, Sejahtera. Hal ini merupakan simbol sekaligus buah nyata dari silaturahim. Terlihat jelas adanya berbagai barang jualan yang dibutuhkan oleh penziarah baik berupa makanan, minuman, pakaian hingga souvenir. Adanya tradisi Jum'at pahing juga menumbuhkan berkah kepada banyak pihak yang meliputi pedagang asongan, pedagang kaki lima, penjual pakaian muslim, penjual atribut dan berbagai barang lainnya yang tentu memberikan keuntungan bagi masyarakat setempat. Selain itu, sejahtera juga berimbas pada jasa angkutan baik angkutan umum maupun pengusaha travel.

Ketiga, Penegasan. Maksudnya adalah tradisi Jum'at pahing memberikan penegasan akan langgeng tradisi ini termasuk di dalamnya adalah aktivitas budaya, aktivitas ritual, simbol dan lain sebagainya yang melekat pada warisan Wali Limbung.

\section{PENUTUP}

Setelah memaparkan hasil penelitian Jejak Wali Limbung dan Tradisi Jum'at pahing dapat disimpulkan bahwa Wali Limbung merupakan Pendakwah yang mewariskan tradisi yang masih dijaga sampai sekarang. Adapun tradisi yang 
dimaksud adalah tradisi Jum'at Pahing yang diwariskan secara turun temurun yang mana menurut keyakinan para pengikutnya bahwa Jum'at Pahing adalah hari baik dan membawa keberkahan dalam hidup. Selain hal itu, tradisi Jum'at pahing juga berkaitan erat dengan berdirinya Masjid Jami' Wali Limbung yang diresmikan pada hari Jum'at Pahing.

Tradisi Jum'at Pahing juga memiliki nilai keagamaan yang dapat mengawal masyarakat untuk tetap memegang teguh nilai-nilai kebajikan di tengah kuatnya arus globalisasi dan moderenisme. Selain itu, dalam tradisi Jum'at Pahing terdapat pelanggeng tradisi ini yaitu faktor ekonomi berupa aktivitas pasar yang tetap lestari dan dapat membantu perekonomian warga sekitar. 


\section{DAFTAR PUSTAKA}

Affandi, Siswanto. 1978. Risalah Wali Limbung Penidiri Masji di Klimbungan. Temanggung.

Amady, El M. Rawa. 2020. "Kearifan Lokal Masyarakat Desa Gambut di Provinsi Riau”. Jurnal Penelitian Sejarah dan Budaya, Vol. 5. No. 2 Oktober 2017. Hal.229-246.

Anies, H.M. Machan. 2009. Tahlilan dan Kenduri (Tradisi Santri dan Kiai). Pustaka Pesantren.

Buhori. 2017. "Islam dan Tradisi Lokal di Nusantara (Telaah Kritis Terhadap Tradisi Pelet Betteng Pada Masyarakat Madura dalam Prespektif Hukum Islam”. Maslahah, Vol. 13. No. 2 Oktober 2017. Hal.229-246.

Fattah, H. Munawir Abul. 2006. Tradisi Orang-Orang NU. Jakarta: Pustaka Pesantren.

Gazalba, Siti. 1968. Pengantar Kebudayaan Sebagai Ilmu. Jakarta: Pustaka Antara.

Koentjaraningrat. 1984. Kebudayaan Jawa. Jakarta: Balai Pustaka.

Maryaeni. 2005. Metode Penelitian Kebudayaan. Jakarta: PT. Bumi Aksara.

Maziyah, Siti, dkk. 2020. "Walisanga: Asal, Wilayah dan Budaya Dakwahnya di Jawa”. Endogami: Jurnal Ilmiah Kajian Antropologi, Vol. 3. No. 2 Juni 2020. Hal.232-239.

Najitama, Fikria. 2018. "Ziarah Suci dan Ziarah Resmi (Makna Ziarah Pada Makan Santri dan Makam Priyayi." Ibda': Jurnal Kebudayan Islam, Vol. 11. No. 129 Agustus 2018. Hal.19-30.

Purwadi. 2007. Upacara Tradisional Jawa Menggali Untaian Kearifan Lokal Yogyakarta: Pustaka Pelajar 2007.

Saleh, Nur Alam. 2019. "Jejak Tuanta Salamka dan Tradisi Ziarah Kubur sebagai Bentuk Budaya Spritual”. Jurnal Penelitian Sejarah dan Budaya, Vol. 5. No. 2 Nopember 2019. Hal.257-275.

Syawal, Ismail. 2019. "Syaikh Abdullah Raqi: Orang Minangkabau Penyebar Islam di Palu pada Abad XVII". Jurnal Penelitian Sejarah dan Budaya, Vol. 6. No. 2 Nopember 2020. Hal.145-170. 


\section{Daftar Wawancara:}

1. Wawancara dengan Mas Ruswandi (Takmir Masjid Jami' Wali Limbung), tanggal 07 Oktober 2015, pukul 15.35 WIB.

2. Wawancara dengan Mas Suryo, pada tanggal 24 Januari 2016, pukul 16.35 WIB.

3. Wawancara dengan Bapak Abdul Rahman, pada tanggal 29 Januari 2016, pukul 10.50 WIB

4. Wawancara dengan Bapak Tamiyis, masyarakat Dusun Kawangan, pada tanggal 7 Februari 2016.

5. Wawancara dengan Bapak Peno, masyarakat Dusun Kawangan, tanggal 7 Februari 2016

6. Wawancara dengan Mbah Bolot, juru kunci Pasar Janggleng. Pada tanggal 7 Februari 2016, pukul 05.55 WIB. 